\title{
Determination of Zinc in Amniotic Fluid in Normal and High Risk Pregnancies
}

\author{
By U. Rösick, Erika Rösick, P. Brätter \\ Hahn-Meitner-Institut für Kernforschung $\mathrm{GmbH}$, Berlin and
}

\section{G. Kynast}

Arbeitsgruppe Perinatale Medizin der Freien Universität Berlin

(Received February 12/October 26, 1982)

Summary: Taking the necessary precautions essential for accurate tràce element analysis, the zinc concentrations of 227 samples of amniotic fluid taken at term were determined by means of neutron activation analysis. Half of the zinc was found to be bound to the particles present in amniotic fluid. In the control group (123 cases) the zinc concentrations ranged from $25-261 \mu \mathrm{g} / \mathrm{l}$ for untreated samples and from $14-143 \mu \mathrm{g} / \mathrm{l}$ when the samples were centrifuged for $10 \mathrm{~min}$ at $22000 \mathrm{~g}$ prior to analysis. The values showed $\log$-normal frequency distributions and were lower than any of the values published in the literature to date.

No statistically significant differences could be found, when zinc concentrations of various risk groups (mothers suffering from gestosis or diabetes mellitus, newborns hypo- or hypertrophic, twin births) were compared with the zinc concentration of the control group. The amniotic fluid zinc concentration is not, therefore, a suitable indicator for the diagnosis of disturbances of the embryonic development.

\section{Zinkbestimmung im Fruchtwasser aus Normalschwangerschaften und aus Risikokollektiven}

Zusammenfassung: Unter Beachtung der für einè präzise Spurenanalytik erforderlichen Vorsichtsmaßnahmen wurde unter Verwendung der Neutronenaktivierungsanalyse in 227 sub partu entnommenen Fruchtwasserproben die Zinkkonzentration bestimmt. Danach ist Zink im Fruchtwasser etwa zur Hälfte an Zellbestandteile gebunden. In der Kontrollgruppe (123 Fälle) lagen die Konzentrationen zwischen $25-261 \mu \mathrm{g} / \mathrm{für}$ nicht vorbehandelte Proben und zwischen 14-143 $\mu \mathrm{g} / \mathrm{l}$, wenn die Proben vor der Analyse für 10 Minuten bei $22000 \mathrm{~g}$ zentrifugiert worden waren. Die Analysenwerte zeigten eine log-normale Häufigkeitsverteilung und lagen niedriger als alle bisher bekannten Literaturangaben.

Beim Vergleich der Zinkkonzentrationen verschiedener Risikokollektive (Erkrankung der Mutter an Gestose oder Diabetes mellitus, Zwillingsgeburten, hypo- und hypertrophe Neugeborene) mit den Werten der Kontrollgruppe konnten keine statistisch signifikanten Unterschiede erkannt werden. Die Zinkkonzentration im Fruchtwasser ist offenbar kein geeigneter Indikator für die Diagnose fetaler Fehlentwicklungen.

\section{Introduction}

The metabolism of the trace element zinc during pregnancy has given rise to particular interest, because the zinc supply of the growing foetus is assumed to be often near the deficiency limit $(1-3)$. Zinc plays an important role in the metabolism of nucleic acids and in the biosynthesis of proteins and is essential for an unimpeded cell growth (4). During pregnancy the embryo's only source of zinc is the maternal serum; the maternal serum zinc level is, however, reduced and there are no readily accessible depots of zinc $(1-3,5-10)$. If the mother suffers 
from an alimentary zinc deficiency, the zinc level drops in the foetus as well. Depending on the extent and duration of such a deficiency, prenatal growth retardation or even disturbances of growth may result $(1,2,3,11)$. Comprehensive literature on this subject can be found in the reviews recently published by Shaw (12) and Kynast \& Saling (13).

In the search for methods for the early diagnosis of such deficiency states several investigations have already been carried out to determine whether there is a correlation between retarded development of the foetus and the amniotic fluid zinc concentration (9, 14-17). Favier et al. $(14,15)$ observed a relationship between the amniotic fluid zinc concentration and the birth weight of the neonate. Prasad (9) found no such correlation which might be possibly attributed to the fact that too few cases were investigated. The most comprehensive study to date on this subject was conducted by Kynast et al. $(16,17)$. They were able to prove that the amniotic fluid zinc concentration in the case of hypotrophic newborns is significantly lower after the 37th week of gestation than in a control group of women with normal pregnancies. Even if the mother has suffered from gestosis or diabetes mellitus during the course of pregnancy the amiotic fluid zinc concentrations at term are significantly lower than those of the control group. The amniotic fluid zinc concentration, therefore, appears to act as suitable indicator for revealing certain risks during pregnancy. Other authors have investigated the influence of other risk factors in pregnancy on the amniotic fluid zinc concentration (18-23). Groups with symptoms of newborn hypoxia in the course of labour (22) and prolonged pregnancies (23) exhibited lower zinc values than the respective control group, whereas age of the mother and rhesus sensitization showed no effect on the zinc values. There are also several studies in which the zinc concentrations were determined in connection with investigations on the antibacterial activity of the amniotic fluid (24-28).

The results of this study are part of an investigation in which the possible functions of zinc and further trace elements in the diagnosis of developmental disturbances in the foetus are to be ascertained using instrumental neutron activation analysis as the method of detection. At an early stage of this study it became clear that our results were considerably lower than any of the values given in the literature $(8,9$, $14-31)$. Thus, in order to provide support for our own results it was essential to devote more attention to the determination of amniotic fluid zinc than was originally intended. This explains why emphasis has been laid on the methodical part of the investigation.

\section{Experimental}

\section{Choice of samples and sampling}

A control group consisting of 123 amniotic fluid samples was formed so that reference values could be obtained. In these cases, from the clinical point of view, the course of the pregnancy was normal and the infant was lively at birth and of normal weight (percentile status (17): P4, P3 - or P3+). A' further 104 samples from so-called high-risk pregnancies were investigated and divided into the following groups:

1. Hypotrophic newborns ( 25 cases with a pericentile status of $\mathbf{P} 1-$ or $\mathbf{P} 2-)$.

2. Hypertrophic newborns (29 cases with a percentile status of $\mathrm{P} 1+$ or $\mathrm{P} 2+$ ).

3. Mothers suffering from gestosis, newborns with normal weights (25 cases with 6 overlapping into group 4).

4. Mothers suffering from diabetes mellitus (latent or manifest), newborns with normal weights (24 casës with 6 overlapping into group 3).

5. Twin births ( 5 cases).

6. Rhesus sensitization ( 2 cases).

Groups 1 and 2 also contain cases in which the mother suffered from gestosis or diabetes mellitus or both during pregnancy. No further differentiation was made. All samples were taken in the "Städtische Frauenklinik Neukölln" in Berlin West between October 1977 and June 1981, by puncturing the amniotic sac at birth. Cleaned cannulas made of highly pure nickel (specially manufactured by Braun, Melsungeni) were used. The samples which were first deep-frozen and stored at $-20^{\circ} \mathrm{C}$ for one week were free of contamination with blood or meconium.

\section{Reagents and standards}

The chemicals used were of analytical grade or better. Highly pure water was obtained by double-distilling deionized water in a quartz apparatus. The zinc concentration in the fresh distillate was below $0.1 \mu \mathrm{g} /$. Zinc standards for the atomic absorption spectrometry were produced from commercially available "Titrisol" solutions (Merck, Darmstadt) and acidified with Merck "Suprapur" $\mathrm{HCl}$ to $0.01 \mathrm{~mol} / \mathrm{l}$.

\section{Analytical method}

After thawing, the amniotic fluid samples were first centrifuged for 10 minutes at $22000 \mathrm{~g}$ (MSE high speed 18 centrifuge with $8 \times 50$ fixed angle rotor) to settle corpuscular and cellular components. The supernatant and the pellet were separated and further treated. In addition, an aliquot of the untreated sample was analysed as a balance control.

The concentration of total protein in each untrieated sample and each supernatant sample was determined by means of Lowry's method (32). From each supernatant sample the absorption spectrum between $320-700 \mathrm{~nm}$ was recorded using $1 \mathrm{~cm}$. quartz cuvettes and double-distilled water as a reference (Beckman mòdel 25 spectrophotometer coupled to a PDP $11 / 40$ computer). The presence of blood or meconium in the samples was determined from the position and intensity of the Soret peak near $400 \mathrm{~nm}$ (33). Corrections had to be made for background absorption in turbid samples.

For the activation analysis the untreated, supernatant and pellet samples were freeze-dried for 6 days at $-10^{\circ} \mathrm{C}$ (Edwards Minifast $600)$. The samples and standards were irradiated in ampoules made of highly pure quartz (specially manufactured by Heraeus, Hanau) for 10 days in the FR-2 reactor in Karisruhe at a thermal neutron flux density of $5-7 \cdot 10^{13} \mathrm{~cm}^{-2} \cdot \mathrm{s}^{-1}$. The irradiation container held up to 18 samples as well as the 3 standards, namely NBS Bovine Liver, NBS Orchard Leavesi and Bowen's Kale. 
After a decay period of 3 months the ampoules were etched for 5 min in concentrated HF in order to remove surface impurities, rinsed with water and acetone and measured for 3 hours in a computerized gamma spectrometer equipped with a sample changer. Even under realistic measuring conditions the well-type $\mathrm{Ge}(\mathrm{Li})$ detector (Princeton Gamma Tech.) provided Gaussian peaks with a full width at half maximum of $2.3 \mathrm{keV}$. The absolute counting efficiency at $1115 \mathrm{keV}$ was 0.036 counts per emitted photon. The zinc content in the samples was determined relative to the NBS Bovine Liver standard (certified zinc content $130 \mu \mathrm{g} / \mathrm{g}$ (34)) through a comparison of the intensity of the $1115 \mathrm{keV}$ line of the ${ }^{65} \mathrm{Zn}$ in the corresponding gamma spectra. The program used to evaluate the spectra was capable of unfolding the ${ }^{65} \mathrm{Zn} /{ }^{46} \mathrm{Sc}$-doublet which had not been completely resolved. Under the abovementioned conditions for irradiation and measurement the detection limit was $0.05 \mathrm{ng}$ zinc (calculated according to Rogers (35)). For conversion of content values into concentrations an amniotic fluid density of $1.015 \mathrm{~kg} / \mathrm{l}$ was assumed (36).

Control measurements with flame atomic absorption spectrometry

The atomic absorption spectrometry of zinc was carried out using a Perkin-Elmer 400 instrument with the following settings: wavelength $213.8 \mathrm{~nm}$, slit $0.7 \mathrm{~nm}$, current supply for the $\mathrm{Zn}$ hollow cathode lamp $16 \mathrm{~mA}$, air-acetylene flame, aspiration rate $2.5 \mathrm{ml} /$ min, integration time $2 \mathrm{~s}$. The deuterium background compensator was switched on for all measurements. In each determination $2.5 \mathrm{ml}$ of undiluted supernatant was aspirated into the flame. The blank value was calculated using double-distilled water as a reference. The zinc concentrations were determined according to the standard addition method and by comparison with a calibration curve which had been established with a set of matrix matched working solutions containing $8 \mathrm{~g} / \mathrm{NaCl}, 50 \mathrm{~g} /$ glycerol as a viscosity adjuster (37), and zinc from a stock solution ranging from 20 to $500 \mu \mathrm{g} /$. The detection limit was $5 \mu \mathrm{g} /$. The standard deviations of individual measurements at zinc concentrations of $100 \mu \mathrm{g} /, 50 \mu \mathrm{g} /$ and $25 \mu \mathrm{g} /$ were $\pm 3 \%, \pm 5 \%$ and $\pm 8 \%$, respectively. The recoveries were determined from a pooled amniotic fluid sample. After zinc additions of $50 \mu \mathrm{g} /, 100 \mu \mathrm{g} / \mathrm{l}$ and $200 \mu \mathrm{g} /$ the following values were obtained: $99.4 \pm 4.4 \%$ $(n=10), 101.9 \pm 3.4 \%(n=10)$ and $100.0 \pm 0.9 \%(n=7)$, respectively.

Due to the relatively high $\mathrm{NaCl}$ concentration in the amniotic fluid samples (about $0.14 \mathrm{~mol} / \mathrm{l}$ ), nonspecific absorption of light occurs during the measurements, which can only be effectively corrected by introducing the background compensator into the light path. This should be mentioned, since nearly all the amniotic fluid zinc determinations with flame atomic absorption spectrometry have so far been carried out without background compensation. As can be seen from the example in table 1 the application of the standard addition method is not a suitable means of correcting nonspecific losses of light. In this example the evaluation by means of linear regression produced straight lines with the same slope. Taking into account the sample dilution the true zinc concentration in the sample was $(32.1 \pm 1.5) \mu \mathrm{g} / 1$, when the background compensator was switched on, and the apparent concentration was $(80.5 \pm 1.8) \mu \mathrm{g} /$, when the measurements were made without background compensätion.

Potassium concentrations were determined in certain amniotic fluid samples by means of flame emission spectrometry using the same Perkin-Elmer instrument with a $\mathrm{N}_{2} \mathrm{O}$-burner at right angle and a red sensitive photomultiplier. $200 \mu \mathrm{l}$ portions of the samples were each diluted with $50 \mathrm{ml} \mathrm{CsCl}$ solution $(1 \mathrm{~g} / \mathrm{CsCl})$ and measured in an air-acetylene flame at $766.5 \mathrm{~nm}$ (slit $0.7 \mathrm{~nm}$ ). Commercially available standard solutions for flame spectrometry (Merck Titrisol 9976, Darmstadt) in the same dilution ratio as the samples were used for calibration. The calibration curve obtained was linear up to $1 \mathrm{mg} /$. Quality control was carried out with the control sera Precinorm $S$ and Precipath $S$ (Boehringer, Mannheim). The precision of the determination was $\pm 7 \%$, and the accuracy was better than $\mathbf{1 . 5 \%}$.
Tab. 1. Influence of background compensation on the determination of zinc in amniotic fluid by means of flame atomic absorption spectrometry ${ }^{\text {a). }}$

\begin{tabular}{|c|c|c|c|c|}
\hline Zinc added $(\mu \mathrm{g} / \mathrm{l})$ & 0 & 50 & 100 & 200 \\
\hline $\begin{array}{l}\text { Signal height without } \\
\text { compensation (V) }\end{array}$ & 1.42 & 2.61 & 3.68 & 5.93 \\
\hline $\begin{array}{l}\text { Signal height with } \\
\text { compensation (V) }\end{array}$ & 0.55 & 1.68 & 2.83 & 4.99 \\
\hline
\end{tabular}

a) Sample dilution $1: 1.25$ with double-distilled water.

\section{Precautions against contamination}

The precautions which must be taken to ensure accurate trace element analysis were carefully observed $(38,39)$. In order to eliminate outside interference from the ubiquitous element zinc, every component was thoroughly checked to make sure it was clean. The sampling cannulas were specially manufactured from highly pure nickel (Braun, Melsungen).

Some of them nevertheless contained considerable zinc impurities. Table 2 shows a summary of the results of the contamination tests carried out on cannulas just received from the factory and after they had been recleaned. The following method of cleaning has proved to be suitable: washing with $10 \mathrm{ml} 0.05 \mathrm{~mol} / \mathrm{EDTA}$ solution and rinsing with $2 \times 20 \mathrm{ml}$ double-distilled water.

Tab. 2. Zinc contamination of amniotic fluid after using newly manufactured and recleaned sampling cannulas made of highly pure nickel.

\begin{tabular}{|c|c|c|c|}
\hline & $\begin{array}{l}\operatorname{Zin}_{\mathbf{N}} \\
\end{array}$ & $\begin{array}{l}\left.\text { determined }{ }^{a}\right) \\
\text { Mean } \pm \text { s.d. } \\
(\mu \mathrm{g} / \mathrm{l})\end{array}$ & $\begin{array}{l}\text { Range } \\
(\mu \mathrm{g} / \mathrm{l})\end{array}$ \\
\hline \multirow{3}{*}{$\begin{array}{l}\text { Pooled amniotic fluid sample } \\
\text { Sampling with new cannulas } \\
\text { Sampling with recleaned } \\
\text { cannulas }^{\text {b) }}\end{array}$} & 5 & $80.6 \pm 2.8$ & $78-86$ \\
\hline & 10 & $154 \pm 71$ & $79-283$ \\
\hline & 11 & $81.6 \pm 3.6$ & $76-88$ \\
\hline
\end{tabular}

a) Measurements by means of flame atomic absorption spectrometry.

b) For each test $2.5 \mathrm{ml}$ of amniotic fluid were taken from the pool.

The $20 \mathrm{ml}$ disposable syringes (Braun, Melsungen, Germany) used to take the amniotic fluid samples were clean. As an occasional check, a syringe was rinsed with $10 \mathrm{ml} 0.1 \mathrm{~mol} / \mathrm{H} \mathrm{HCl}$ and the zinc content in the rinsing solution was then analysed by carbon furnace atomic absorption spectrometry as described in l.c. (40). The highest zinc value found was $0.2 \mu \mathrm{g} / \mathrm{l}$.

Plastic containers and the tips of the pipettes were soaked overnight in $6 \mathrm{~mol} / / \mathrm{HNO}_{3}$ and then washed in double-distilled water. The contamination test with $0.1 \mathrm{~mol} / \mathrm{HCl}$ showed values below $0.1 \mu \mathrm{g} /$.

The quartz ampoules used for the reactor irradiation were precleaned according to the procedure prescribed in l.c. (41). The samples were weighed into the ampoules under clean room conditions and sealed with the help of a quartz burner. Since the samples were relatively small ( $<30 \mathrm{mg}$ ) compared with the quartz ampoule weight $(>350 \mathrm{mg}$ ), the blank value acquired particular importance. Table 3 contains the results of the blank value measurements of empty ampoules. As can be seen from this table it was possible to lower the blank value to a negligible level only by means of etching the ampoules with concentrated HF, which itself can be a dangerous undertaking, since several ampoules exploded during etching. 
Tab. 3. Zinc contamination of the irradiation ampoules after application of different cleaning procedures following irradiation.

\begin{tabular}{llll}
\hline & $\begin{array}{l}\text { Zinc determined } \\
\text { 1st Batch } \\
(\mu \mathrm{g} / \mathrm{g})\end{array}$ & $\begin{array}{l}\text { 2nd Batch } \\
(\mu \mathrm{g} / \mathrm{g})\end{array}$ \\
\hline $\begin{array}{l}\text { Without washing } \\
\begin{array}{l}\text { Washing with } \\
\text { Extran }\end{array}\end{array}$ & $22 \pm 43 \quad(\mathrm{n}=10)$ & $43 \pm 14 \quad(\mathrm{n}=10)$ \\
$\begin{array}{l}\text { Etching with } \\
\text { conc. HF }\end{array}$ & $0.1 \pm 0.1(\mathrm{n}=5)$ & $11 \pm 6 \quad(\mathrm{n}=5)$ \\
\hline
\end{tabular}

a) Mean \pm s. d.

\section{Statistical methods}

The symmetry of the frequency distribution for zinc and protein in the control group was tested before and after data transformation by calculating the skewness and by applying the KolmogorovSmirnov test. The fit of the calculated to the sum frequency distribution obtained experimentally was considered to be good, if the test value of the Kolmogorov-Smirnov test was lower than Lilliefors' $10 \%$ level of significance; and moderate, if it was between the critical values for $10 \%$ and $5 \%$ (42). If the test value exceeded the $5 \%$ limit a lack of fit was assumed.

\section{Results}

Quality control of zinc determination in amniotic fluid

\section{Within-run-precision}

This is caused by local differences in the neutron flux density during irradiation inside an irradiation container. At the beginning of this study in two irradiation cans all the ampoules were equipped with a flux monitor of pure iron and irradiated as described above in the FR-2 reactor. The results of the flux measurements are given. in table 4.

Tab. 4. Fluctuations in the flux density of thermal neutrons $\varnothing$ in the irradiation container.

\begin{tabular}{lllll}
\hline $\begin{array}{l}\text { Irradiation } \\
\text { container }\end{array}$ & $\begin{array}{l}\text { Number of } \\
\text { ampoules }\end{array}$ & $\left.\mathrm{s}_{\mathrm{b}}{ }^{\mathrm{a}}\right)$ & $\delta_{\min }$ & $\delta_{\max }$ \\
\hline 1 & 22 & $\pm 1.2 \%$ & $-2.3 \%$ & $+2.0 \%$ \\
2 & 17 & $\pm 1.3 \%$ & $-2.5 \%$ & $+2.5 \%$ \\
\hline a) $\mathrm{s}_{\mathrm{o}} \quad=\left(\delta_{\mathrm{i}}^{2} /(\mathrm{n}-1)\right)^{1 / 2} ;$ & & \\
$\delta_{\mathrm{i}}=100 \cdot\left(\varnothing_{\mathrm{i}}-\varnothing_{\text {mean }}\right) / \varnothing_{\text {mean }} ;$ & & \\
$\varnothing_{\text {mean }}$ & $=\Sigma \varnothing_{\mathrm{i}} / \mathrm{n}$.
\end{tabular}

\section{Between-run-precision}

For the regular supervision of the analysis the zinc contents of the standard reference materials Bowen's Kale and NBS Orchard Leaves were evaluated
Tab. 5. Control of precision and accuracy on the determination of zinc by means of neutron activation analysis.

\begin{tabular}{llll}
\hline & & \multicolumn{2}{l}{ Orchard Leaves Bowen's Kale } \\
NBS 1571
\end{tabular}

a) Mean \pm s. d.

using NBS Bovine Liver as a refèrence. The resülts for 47 irradiation cans are listed in table 5 . The coefficients of variation was $\pm 3.5 \%$ for Bowen's Kạle and still about $\pm 7.0 \%$ for NBS Orchard Leaves, but the mean zinc contents found agreed with the certified and recommended values.

\section{Overall precision}

During centrifugation the total sample is separated at a ratio of $f:(1-f)$ into the supernatant $U$ and the pellet $P$. Using this ratio it is possible to calculate the zinc concentration in the total sample $\left(c_{s}\right)$ from the zinc values of the supernatant sample $c_{\mathrm{u}}$ and the pellet sample $c_{\mathrm{p}}$ according to the equation:

$$
c_{\mathrm{s}}=\mathrm{f} \cdot c_{\mathrm{u}}+(1-\mathrm{f}) \cdot c_{\mathrm{p}}
$$

If the calculated value $c_{\mathrm{s}}$ diffèrs greatly from the value analysed for the untreated sample $\left(c_{\mathrm{g}}\right)$, there are either marked inhomogenities in the sample, or element losses and/or contamination have occurred during one of the analytical steps âfter centrifugation. The ratio $c_{s} / c_{g}$, therefore, provides us with an opportunity to check whether the analytical data are plausible. If the ratio is outside a prescribed toler: ance range there is reason to suspect that systematic errors are responsible for the distortion in the result.

In the experimental work, a complete set of data was available for 223 samples including the 18 samples which contained meconium. Four samples were excluded from further evaluation because their $c_{s} / c_{\mathrm{g}}-$ ratio was either over 1.4 or below 0.8 . For the remaining 219 samples a $c_{s} / c_{g}$ ratio of $1.059 \pm 0.107$ was obtained, which was significantly greatēr $(P<0.001)$ than the expected value 1 . The reason for this was a later discovered geometrical error in the measurement of the pellet samples in the welltype $\mathrm{Ge}(\mathrm{Li})$ detector. Hence, the zinc values determined for the pellet samples were a little to high. 
Comparison of determination methods:

Instrumental neutron activation analysis versus flame atomic absorption spectrometry

For the comparison, 10 amniotic fluid samples containing neither blood nor meconium were centrifuged in the manner described. The supernatant zinc was analysed as follows:

(I) by means of instrumental neutron activation analysis,

(II) by means of flame atomic absorption spectrometry using the standard addition method, and

(III) by means of flame atomic absorption spectrometry using a calibration curve obtained with standards adapted to the matrix.

The results are listed in figure 1 . The correlation coefficients for the comparisons (I) vs. (II), (I) vs. (III) and (II) vs. (III) were 0.996, 0.991 and 0.994 , respectively. The corresponding standard errors of estimate were $3.1 \mu \mathrm{g} /, 4.6 \mu \mathrm{g} / \mathrm{l}$ and $3.9 \mu \mathrm{g} /$. The regression lines do not show any statistically significant deviation from the expected values for intercept $(a=0)$ and slope $(b=1)$.

Furthermore, 28 samples which had been centrifuged separately for instrumental neutron activation analysis and flame atomic absorption spectrometry were investigated. These results have also been included in figure 1 . The correlation coefficient in this case is somewhat lower $(0.986)$ and the standard er-

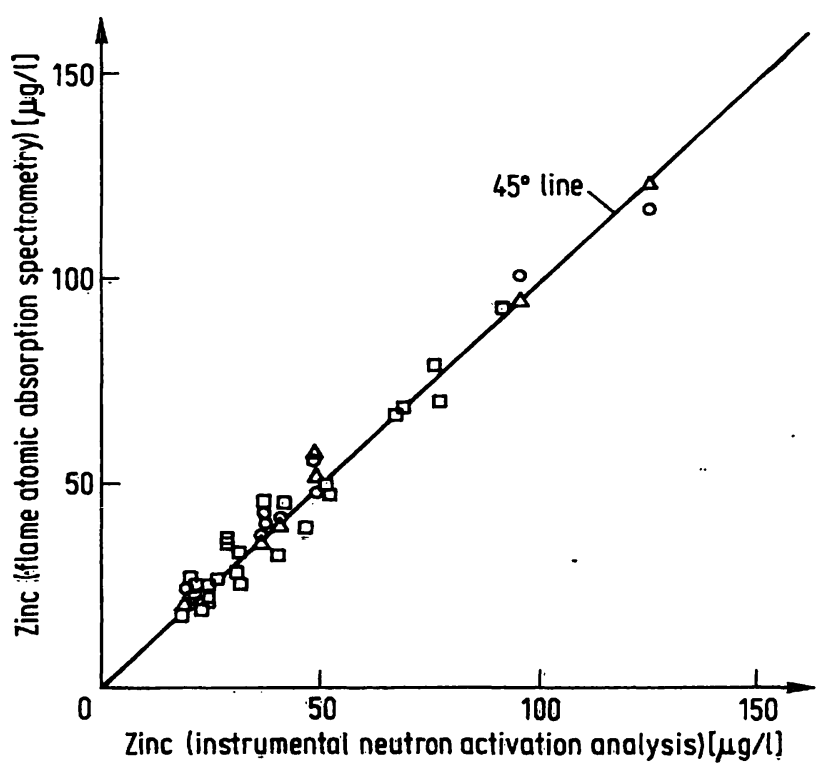

Fig. 1. Comparison between results obtained by instrumental neutron activation analysis and flame atomic absorption spectrometry for the zinc concentration in the supernatant of centrifuged samples of amniotic fluid.

$(O)=$ Determination with the standard addition method,

$(\Delta)=$ determination with a calibration curve,

$(\square)=$ separately centrifuged samples. ror of estimate somewhat higher $(5.2 \mu \mathrm{g} / \mathrm{l})$, but again no significant deviations from the theoretical $45^{\circ}$ line were found.

This comparison of methods proves that both analytical procedures can be considered as equally good when used to obtain amniotic fluid zinc concentrations. The results also show that no zinc losses occurred when the samples were freeze-dried.

The influence of the centrifugation conditions

Amniotic fluid is not a homogenous liquid, but contains at birth suspended vernix flakes, lanugo hairs, epidermis scales, as well as other cellular and corpuscular components (44). The analytical conditions described in the literature for the zinc determination in amniotic fluid contain widely varying procedures for the pre-treatment of the samples. They include recommendations for measuring without treating the sample $(8,9,19,21-23)$, after 1: 10 dilution with distilled water $(14,15)$, after filtration $(24,27-29)$, after centrifugation $(25,26,30)$, after centrifugation of turbid samples $(16-18)$ and after precipitation with trichloroacetic acid and centrifugation (31).

For a better comparison of our results with the literature data, it seemed to be advisable to investigate the effect of the centrifugation conditions on the element distribution between supernatant and pellet. For this purpose four $5 \mathrm{ml}$ aliquots of a pooled amniotic fluid sample were each centrifuged for $10 \mathrm{~min}$ at different speeds and, after phase separation, analysed by means of instrumental neutron activation analysis in the manner described. The results are listed in figure 2. This shows those elements which

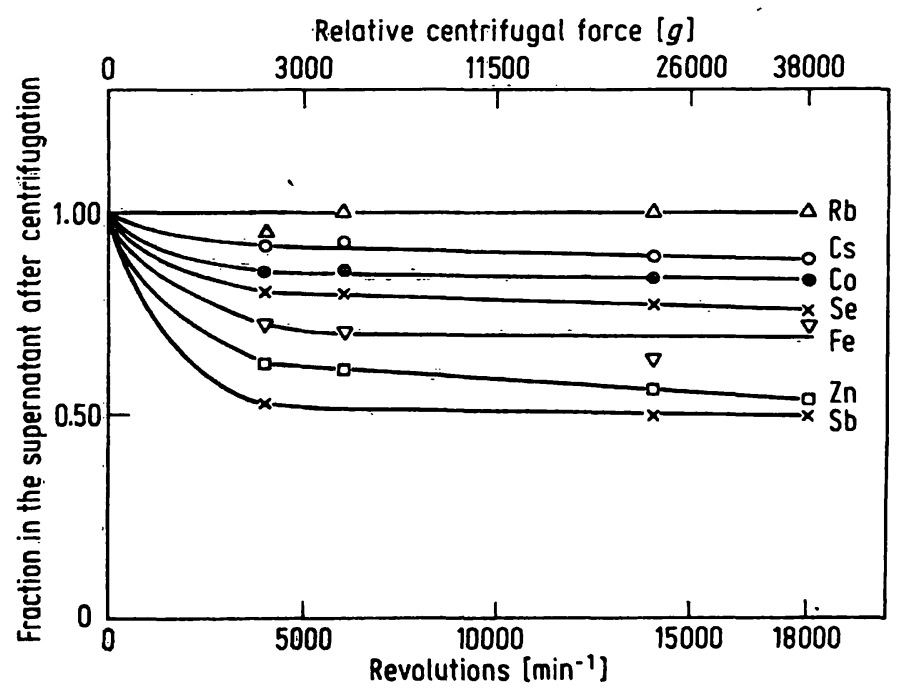

Fig. 2. Influence of centrifugation conditions on the distribution of different trace elements between supernatant and pellet of a pooled amniotic fluid sample. All samples were centrifuged for 10 minutes. 
could be determined simultaneously after long term irradiation. The different behaviour of the elements investigated can be clearly recognized. For example, about half of the zinc is bound to particles, whereas all of the rubidium remains in the solution. The relative centrifugal force has an influence on the element distribution between the two phases up to $3000 \mathrm{~g}$. A further increase only causes slight changes.

After evaluation of all measurements for zinc a mean $c_{\mathrm{u}} / c_{\mathrm{g}}$ ratio of $0.65 \pm 0.15$ was determined and a close correlation was observed between the zinc concentration values in corresponding supernatant and untreated samples $(\mathrm{r}=0.90, \mathrm{P}<0.001)$.

\section{Effect of storing the samples at $-20^{\circ} \mathrm{C}$}

For logistic reasons the amniotic fluid samples could not be analysed until a week after they had been obtained. It was unknown whether storage of the samples at $-20^{\circ} \mathrm{C}$ and thawing caused intact cells in the amniotic fluid to lyse or become permeable and to lose some or all electrolytes and trace elements, thus giving rise to false analytical results. We therefore investigated whether storage had any effect on the distribution of elements between supernatant and pellet. Both zinc and potassium were measured, since intracellular accumulation of potassium is greater than that of zinc (45).

Our procedure was as follows: 10 amiotic fluid samples were divided into two equal parts not later than 15 min after sampling. Part A was immediately centrifuged (10 min at $3000 \mathrm{~min}^{-1}$ ) and the supernatant was separated from the pellet and later analysed for zinc and potassium. Part B was deep-frozen without any further pre-treatment, stored for one week at $-20^{\circ} \mathrm{C}$ and after being thawed it was centrifuged and analysed in the same manner as Part A. The results are summarized in table 6. Students t-tests showed no deviation from zero for the concentration differences $c_{A}-c_{B}$ for either element. Likewise, the concentration ratios $c_{A} / c_{B}$ showed no deviation from the expected value 1 .
Similar results were also found for 14 more samples which had been stored in a refrigerator at $+8^{\circ} \mathrm{C}$ for between 3 hours and 4 days after sampling. Here, the mean concentration differences were $(0.1 \pm 4.1)$ $\mu \mathrm{g} / \mathrm{l}$ for zinc and $(0.5 \pm 1.7) \mathrm{mg} / \mathrm{l}$ for potassium. The corresponding concentration ratiọ̧ were $0.994 \pm$ 0.062 and $0.998 \pm 0.009$, respectively.

The above results demonstrate that storing untreated samples for one week at $-20^{\circ} \mathrm{C}$ has no effect on the analytical values for zinc.

\section{Effects of blood and meconium}

As the zinc content of erythrocytes is about 200 times as high as that in amniotic fluid even small amounts of contaminating blood may distort the analytical results. For this reason all samples in which blood was visible were discarded. The optical spectra știll showed a haemoglobin péak at $414 \mathrm{~nm}$ with net absorbances between $0.002-0.40$ in $70 \%$ of the remaining samples. In order to keep the error due to the erythrocyte zinc within acceptable limits we included only those samples in this investigation in which the net absorbance of the haemoglobin peak at $414 \mathrm{~nm}$ was less than 0.10 . As the following assessment shows this limit is low enough. The erythrocytes contain about $14 \mathrm{mg} / \mathrm{l}$ zinc (45) and $340 \mathrm{~g} / \mathrm{l}$ haemoglobin (46). The molar absorption coefficient of haemoglobin at $414 \mathrm{~nm}$ is $115 \mathrm{~cm}^{2} / \mathrm{mol}$ (33). If an amniotic fluid sample shows a peak here with a net absorbance of 0.10 , this indicates an in= crease in the zinc concentration of $0.6 \mu \mathrm{g} / \mathrm{l}$. It is possible to confirm that this value is in the right order of magnitude by other means. For the peak absorbance given the amniotic fluid contamination due to haemoglobin iron is already $75 \mu \mathrm{g} / \mathrm{l}$. Since the $\mathrm{Fe} / \mathrm{Zn}$ molar ratio in the erythrocytes is about 100 (45) a zinc contamination of $0.8 \mu \mathrm{g} / 1$ would thus result.

It is known that amniotic fluid samples containing meconium show a higher zinc level (14-17). The presence of larger quantities can easily be identified by virtue of the dark green colour meconium imparts

Tab. 6. Influence of sample freezing on the amniotic fluid concentrations of zinc and potassium.

\begin{tabular}{lllcc}
\hline & $\begin{array}{l}\text { No. of } \\
\text { samples }\end{array}$ & $\begin{array}{l}\text { Concentration } \\
\text { range }\end{array}$ & $\begin{array}{l}\left.\text { Difference } c_{A}-c_{B}{ }^{a}\right) \\
\text { Mean } \pm \text { s.d. }\end{array}$ & $\begin{array}{l}\text { Ratio } c_{A} / c_{B}{ }^{a)} \\
\text { Mean } \pm \text { s.d. }\end{array}$ \\
\hline $\mathrm{Zn}^{\prime \prime}$ & 10 & $40-213 \mu \mathrm{g} / \mathrm{l}$ & $(1.4 \pm 4.2) \mu \mathrm{g} / \mathrm{l}$ & $1.020 \pm 0.062$ \\
$\mathrm{~K}$ & 10 & $142-181 \mathrm{mg} / \mathrm{l}$ & $(-0.2 \pm 1.8) \mathrm{mg} / \mathrm{l}$ & $1.000 \pm 0.011$ \\
\hline
\end{tabular}

\footnotetext{
a) $c_{A}=$ concentration in Part $A$ of the sample which was centrifuged immediately after sampling.

$c_{B}=$ concentration in Part B of the sample which was stored at $-20^{\circ} \mathrm{C}$ for one week and centrifuged after thawing.
} 
Tab. 7. Influence of sample contamination with meconium on the amniotic fluid zinc concentrations.

\begin{tabular}{lllrr}
\hline $\begin{array}{l}\text { Peak intensity } \\
\text { at 405 nm }\end{array}$ & $\begin{array}{l}\text { No. of } \\
\text { samples }\end{array}$ & Colour & \multicolumn{2}{c}{$\begin{array}{l}\text { Zinc concentration }(\mu g / l) \\
\text { untreated } \\
\text { supernatant } \\
\text { samples }\end{array}$} \\
\hline $0.030-0.100$ & 7 & yellowish & $262 \pm 69$ & $167 \pm 80$ \\
$0.101-0.200$ & 7 & yellowish-green & $331 \pm 124$ & $174 \pm 61$ \\
$0.201-0.800$ & 4 & green & $702 \pm 403$ & $375 \pm 208$ \\
\hline
\end{tabular}

to amniotic fluid. In smaller concentrations it can be detected using the Soret peak of meconium porphyrins at $405 \mathrm{~nm}$ in the optical spectra (33). The results obtained in this study for meconium-containing amniotic fluid samples are summarized in table 7. The meconium contamination of half of the samples listed was only detected with the aid of the optical spectra. We also analysed samples with visible meconium staining in order to demonstrate the connection between the peak absorbance $\Delta \mathbf{A}_{405} \mathrm{~nm}$ and the zinc concentration $\left(c_{\mathrm{Zn}}\right)$. The equations of the regression lines were as follows:

for the untreated samples:

$c_{\mathrm{Zn}}=185+1101 \cdot \Delta \mathrm{A}_{405 \mathrm{~nm}}(\mu \mathrm{g} / \mathrm{l})$

for the supernatant samples:

$c_{\mathrm{Zn}_{\mathrm{n}}}=110+513 \cdot \Delta \mathrm{A}_{405 \mathrm{~nm}}(\mu \mathrm{g} / \mathrm{l})$.

with statistically significant $(P<0.001)$ correlation coefficients of 0.86 and 0.84 , respectively. The results reveal that the optical spectra of amniotic fluid are $\cdot$ a suitable tool for detecting zinc contamination by meconium, even at lower concentration levels.

Zinc and protein concentrations in amniotic fluid from normal and high risk pregnancies

The analytical results for the control group are listed in tables 8 and 9. Skewed frequency distributions were found for both zinc and protein. The asymmetry disappers, however, when the data were transformed into a logarithmic scale. This agrees with the results of the Kolmogorov-Smirnov test, according to which żinc and protein are not normally but lognormally distributed.

Duration of pregnancy was not found to have any influence on the zinc values, as was the case with the investigations of Kynast et al. (17) and Brandes et al. (31). The analysis of variances of the data, which were divided into four groups as a function of the duration of pregnancy (see fig. 3), revealed no statistically significant changes between the different mean values.
Tab. 8. Amniotic fluid zinc concentrations at term in normal pregnancies.

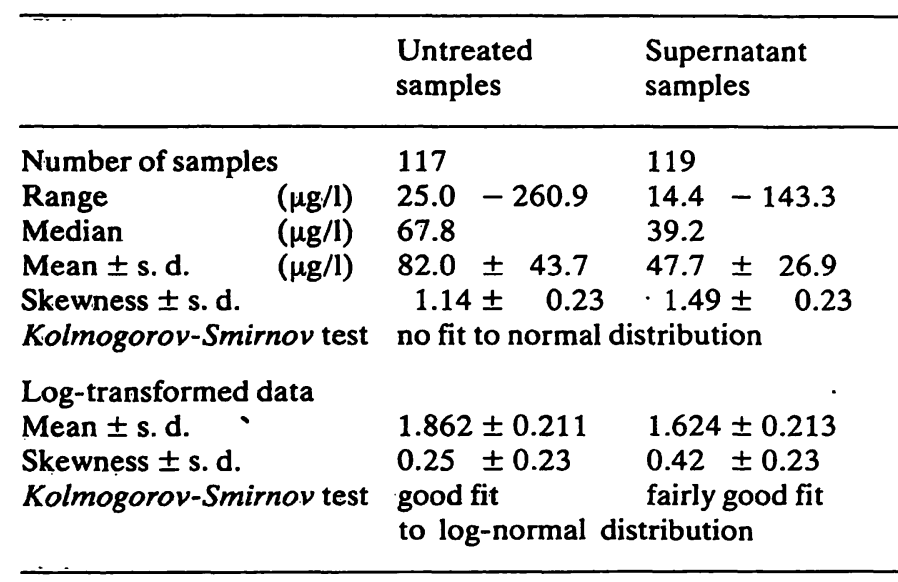

Tab. 9. Amniotic fluid protein concentrations at term in normal pregnancies.

\begin{tabular}{|c|c|c|}
\hline . & $\begin{array}{l}\text { Untreated } \\
\text { samples }\end{array}$ & $\begin{array}{l}\text { Supernatant } \\
\text { samples }\end{array}$ \\
\hline \begin{tabular}{lc} 
Number of samples \\
Range & $(\mathrm{g} / \mathrm{l})$ \\
Median & $(\mathrm{g} / \mathrm{l})$ \\
Mean \pm s. d. $\quad(\mathrm{g} / \mathrm{l})$ \\
Skewness \pm s. d. \\
\multicolumn{2}{l}{ Kolmogorov-Smirnov test }
\end{tabular} & $\begin{array}{l}123 \\
1.02-4.96 \\
2.32 \\
2.42 \pm 0.69 \\
0.97 \pm 0.22 \\
\text { no fit to normal }\end{array}$ & $\begin{array}{l}122 \\
0.95-4.14 \\
1.99 \\
2.03 \pm 0.57 \\
0.72 \pm 0.22 \\
\text { distribution }\end{array}$ \\
\hline $\begin{array}{l}\text { Log-transformed data } \\
\text { Mean } \pm \text { s. d. } \\
\text { Skewness } \pm \text { s. d. } \\
\text { Kolmogorov-Smirnov test }\end{array}$ & $\begin{array}{l}0.366 \pm 0.121 \\
0.06 \pm 0.22 \\
\text { good fit to log-nc }\end{array}$ & $\begin{array}{l}0.191 \pm 0.121 \\
-0.07 \pm 0.22 \\
\text { ormal distribution }\end{array}$ \\
\hline
\end{tabular}

Although it is statistically significant the correlation between zinc and protein in amniotic fluid is not very marked. Using logarithmically transformed data the correlation coefficient were $r=0.45(P<0.001)$ for the untreated samples and $r=0.33(P<0.001)$ for the supernatant samples. Since in amniotic fluid zinc is totally or almost totally bound to proteins (40), we had expected a closer correlation.

As a result of the weak correlation between zinc and protein the zinc/protein ratio fluctuates similarly to the zinc values themselves. The inter-individual vari- 


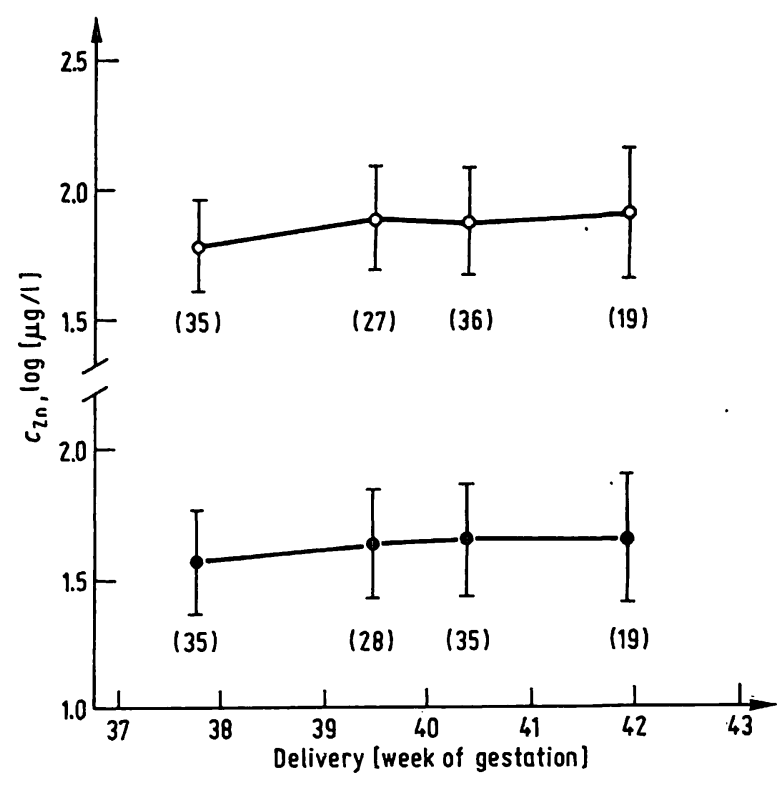

Fig. 3. Changes in the amniotic fluid zinc level as a function of the duration of gestation. The figures in parentheses show the number of cases in each group.

$\bigcirc$ untreated samples

- supernatants

ations of the amniotic fluid zinc concentrations cannot, therefore, be explained by changes in the protein/water ratio, which was demonstrated by Jürgensen \& Behne (47) for the behaviour of the protein bound elements zinc and selenium in human sera.

The amniotic fluid zinc levels of the high risk groups are presented in figure 4 , together with the values of the control group. As was shown by statistical tests using logarithmically transformed data, none of the high risk groups differs in variance and mean value from the control group, a result which contradicts the findings of Kynast et al. (17). Even in the two cases with rhesus sensitization the zinc levels were within the normal range.

\section{Discussion}

The amniotic fluid zinc concentrations at term determined in this study do not agree with any of the data given in the literature $(8,9,14,15,17,18,21-31)$. Figure 5 shows a detailed comparison. Athough coefficients of variation between 30 and $100 \%$ had been found in all of the investigations, the difference remains obvious. On careful scrutiny of the results it is apparent that the observed discrepancy is not due to a single cause, but that several factors are involved. The purpose of the following discussion is to attempt to estimate their influence on the analytical results.

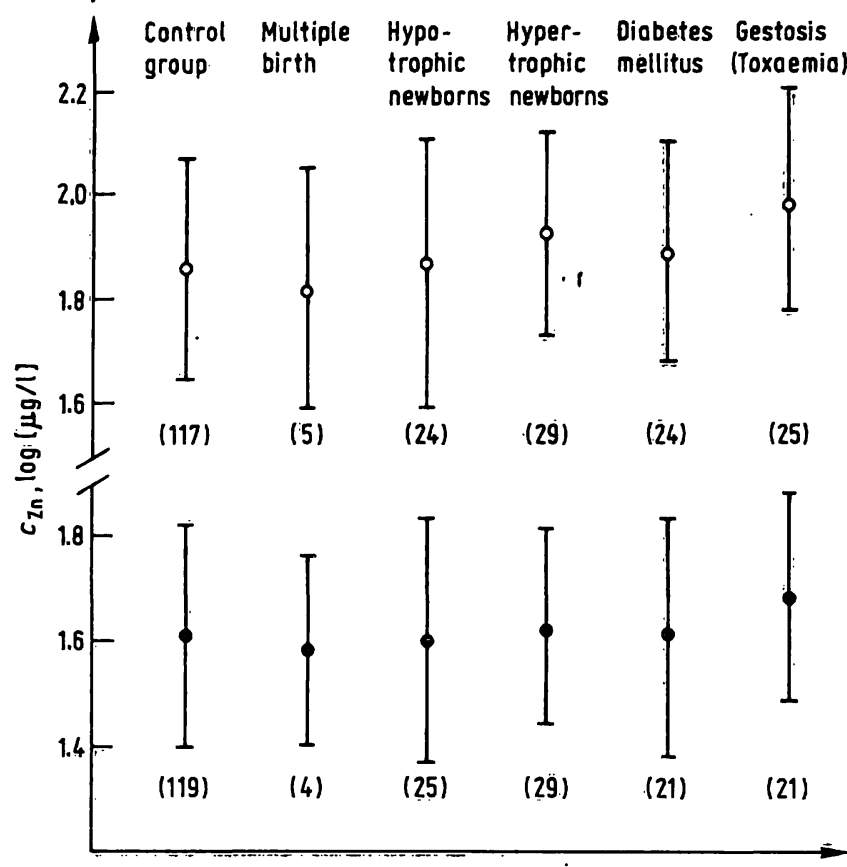

Fig. 4. Comparison of amniotic fluid zinc levels in different risk groups. The lines represent the range $\bar{x} \pm s$. $d$. of the logtransformed data. The figures in parentheses show the number of cases in each group.

$O$ untreated samples

supernatants

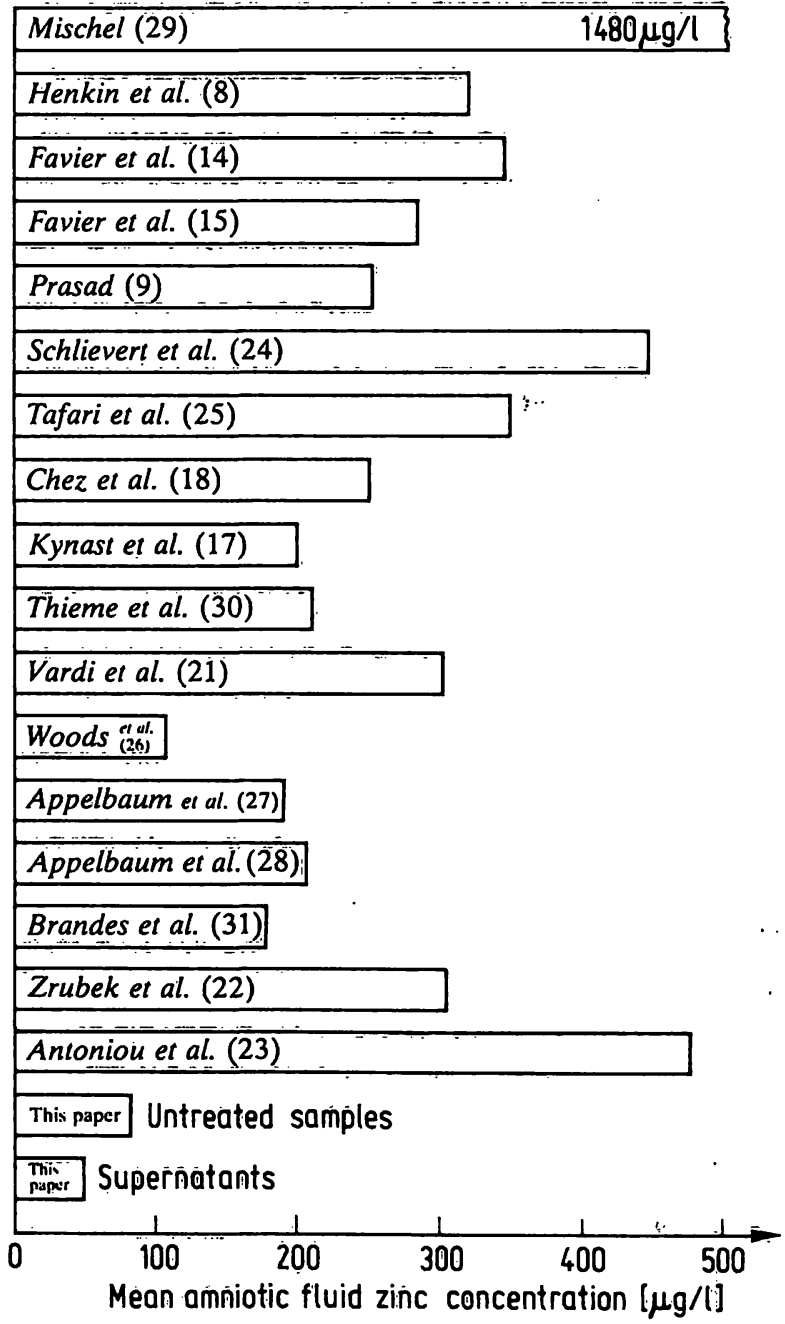

Fig. 5. Amniotic fluid zinc levels at term in normal pregnancies; a comparison of values already published in the literature with the results of this investigation. 


\section{Contamination of samples}

Contamination of samples with blood was a less important factor than we originally feared. Even if blood-stained samples are rejected on the basis of a visual assessment alone, the analytical error due to zinc from haemolyzed erythrocytes is less than $5 \mu \mathrm{g} / \mathrm{l}$. The situation with meconium-containing samples is quite different. As even small amounts of meconium have a marked effect on the results we recommend that the samples should be selected on the basis of optical amniotic fluid spectra rather than by the naked eye.

\section{Pre-treatment of samples}

As our results show, centrifugation of the samples greatly affects the zinc values. For this reason all the samples should be subjected to the same pre-treatment, otherwise the results are no longer comparable.

\section{Analytical method}

To date little attention has been paid to the fact that when flame atomic absorption spectrometry is used to determine zinc in undiluted samples of amniotic fluid unspecific absorption of light occurs during the measurements. The analytical results given in l.c. (8, $9,14,15,17,18,21,24-28,31$ ) could therefore be too high. Diluting the sample with distilled water at a ratio of $1: 10$, as described by Favier et al. $(14,15)$, does reduce the unspecific absorption. However, zinc cannot be determined in samples containing less than $50 \mu \mathrm{g} / \mathrm{l}$. It is therefore advisable to use background compensation.

\section{Stage of pregnancy}

According to Kynast et al. (17) the zinc concentration increases between the 35th and 42nd weeks of gestation. In cases of mild and severe hypotrophy the onset of this increase comes later and is less pronounced. Chez et al. (18) and Brandes et al. (31) obtained similar concentration curves in normal pregnancies, while Antoniou et al. (23) observed lower amniotic fluid zinc concentrations in prolonged pregnancies than in normal pregnancies. However, in the later study the mean value of the control group is strikingly high. Our results, which were obtained with samples taken from the 37 th to the 42nd weeks of pregnancy, show hardly any trend toward an increase in the amniotic fluid zinc level as pregnancy progresses (see fig. 3). Moreover, the mean value for the hypotrophic newborns does not differ from that obtained in normal pregnancies (see fig. 4). We assume that a possible explanation for the apparent contradiction in the various sets of results is that the raised zinc levels in the different sub-groups in the studies mentioned were caused by undetected contamination of the samples with meconium. Since, according to Fujikara \& Klionsky (48), meconiumstaining is disproportionately uncommon in premature infants, but its incidence is increased in neonates with birth weights greater than $3500 \mathrm{~g}$, this would explain why Kynast et al. (17) found lower zinc concentrations in the group with hypotrophic newborns than in the control group.

\section{Demographic factors}

The study conducted by Tafari et al. (25) in Ethopia had shown that demographic factors must be taken into account when interpreting results. They determined significantly lower amniotic fluid zinc concentrations in "underprivileged" women than in "privileged" woman and assumed that a zinc-deficient diet of the "underprivileged" women could be the cause. In contrast, Woods et. al. (26) found no difference between the amniotic fluid zinc concentrations at term in black and white women in Cape Town, South Africa. Since the mean value of $(106 \pm 61) \mu \mathrm{g} / \mathrm{l}$ in this study was low in comparison with the results of Tafari et al. (25) the authors postulated that both populations of this region had a dietary deficiency of zinc. The comparable mean value of our normal group was $(48 \pm 27) \mu \mathrm{g} / \mathrm{l}$. According to the criteria of Tafari et al. (25) and Woods et al. (26) this value would reveal extreme zinc deficiency. We do not share this conclusion. The patients in our investigation showed no signs of zinc malnutrition and the serum values of the mothers and the newborns did not deviate from the norm (49). However, this example demonstrates that caution is imperative when drawing conclusions on the basis of amniotic fluid zinc levels.

\section{Acknowledgement}

We would like to thank the staff of the Nuclear Research Centre in Karlsruhe for irradiating the samples free of charge. 


\section{References}

1. Jameson, S. (1976) Acta Med. Scand. Suppl. 593, 3-49.

2. Jameson, S. \& Ursing, I. (1976) Acta Med. Scand. Suppl. $593,50-64$.

3. Jameson, S. (1980) In: "Zinc in the Environment", Part II: "Health Effects", (Nriagu, J. E. ed.), pp. 183-196, John Wiley \& Sons, New York.

4. Underwood, E. J. (1977) "Trace Elements in Human and Animal Nutrition", ed. 4, pp. 196-242, Academic Press, New York.

5. Halsted, J. A., Hackley, B. M. \& Smith jr., J. C. (1968) Lancet II, 278-279.

6. Hähn, N. \& Fuchs, C. (1974) Zbl. Gynäkol. 96, 1520-1523.

7. Hambidge, K. M. \& Droegemueller, W. (1974) Obstet. Gynecöl. 44, 666-672.

8. Henkin, R. I., Marshall, J. R. \& Meret, S. (1971) Am. J. Obstet. Gynecol. 110, 131-134.

9. Prasad, L. S. (1974) Annales Nestlé 38, 30-38.

10. Hurley, L. S. \& Swenerton, H. (1971) J. Nutr. 101, 597603.

11. Soltan, M. H. \& Jenkins, D. M. (1982) British J. Obstet. Gynecol. 89, 56-58.

12. Shaw, J. C. L. (1979) Am. J. Dis. Child. 133, 1260-1268.

13. Kynast, G. \& Saling, E. (1980) J. Perinat. Med. 8, 171-182.

14. Favier, M., Yacoub, M., Racinet, C. \& Marka, C. (1971) Rev. Franç. Gynécol. 66, 623-627.

15. Favier, M., Yacoùb, M., Racinet, C., Marka, C., Chabert, P. \& Benbassa, A. (1972) Rev. Franç. Gynécol. 67, 707-714.

16. Kynast, G., Wagner, N., Saling, E. \& Herold, W. (1978), J. Perinat. Med. 6, 231-239.

17. Kynast, G., Saling, E. \& Wagner, N. (1979) J. Perinat. Med. 7, 69-77.

18. Chez, R. A., Henkin, R. I. \& Fox, R. (1978) Am. J. Obstet. Gynecol. 52, 125-127.

19. Shearer, T. R., Lis, E. W., Johnson, K. S., Johnson, J. R. \& Prescott, G. H. (1979) Nutr. Rep. Int. 19, 209-213.

20. Shearer, T. R., Lis, E. W., Johnson, K. S., Johnson, J. R. \& Prescott, G. H. (1979) Proc. Soc. Exp. Biol. Med. 161, 382385

21. Vardi, P., Hidvégi, J., Linderné Szotyori, K., Konrad, S. \& Somos, P. (1979) Magyar Nöorvosok Lapja 42, 429-432.

22. Zrubek, H., Czekierdowska, D., Hruczkowski, L. \& Oleszczuk, J. (1980) Ginekologia Polska 5I, 245-247.

23. Antoniou, K., Vassilaki-Grimani, M., Lolis, D. \& Grimanis, A. P. (1982) J. Radioanal. Chem. 70, 77-84.

24. Schlievert, P., Johnson, W. \& Galask, R. P. (1976) Am. J. Obstet. Gynecol. 125, 899-905.

25. Tafari, N., Ross, S. M., Naeye, R. L., Galask, R. P. \& Zaar, B. (1977) Am. J. Obstet. Gynecol. 128, 187-189.
26. Woods, D. L., Malan, A. F., Gunston, K. D., Steyn, D. L., Meyer, J. \& Dempster, W. S. (1979) S. Afr. Med. J. 55, 1059-1060.

27. Appelbaum, P. C., Ross, S. M., Dhupelia, I, \& Naeye, R. L (1979) Am. J. Obstet. Gynecol. 135, 82-84.

28. Appelbaum, P. C., Shulman, G., Chambers, N. L., Simon, N. V., Granados, J. L., Fairbrother, P. F. \& Naeye, R. L. (1980) Am. J. Obstet. Gynecol. 137, 579-582.

29. Mischel, W. (1960) Geburtsh. Frauenheilk. 6, 584-589.

30. Thieme, R., Schramel, P. \& Mahr, W. (1980) Geburtsh Fraueriheilk. 40, 185-187.

31. Brandes, J. M., Lightman, A., Ittskovitz, J. \& Zinder, $\mathbf{O}$ (1980) Biol. Neonate 38, 66-70.

32. Lowry, O. H., Rosebrough, N. J., Farr, A. L. \& Randall, R. J. (1951) J. Biol. Chem. 193, 265-275.

33. Van Kessel, H. (1973) in "Amniotic Fluid, Research and Clinical Applications", (Fairweather, D. V. S. \& Eskes, T. K. A. B. eds.), pp. 150-169, Excerpta Medica, Amsterdam.

34. Lafleur, P. D. (1974) J. Radioanal. Chem. 19, 227-232.

35. Rogers, V. C. (1970) Anal. Chem. 42, 807-808.

36. Melchert, F. (1973) Gynäkologe 6, 156-168.

37. Butrimovitz, G. P. \& Purdy, W. C. (1977) Anal. Chim. Acta $94,63-73$.

38. Reimold, E. W. \& Besch, D. J. (1978) Clin. Chem. 24, 675680.

39. Behne, D. (1981) J. Clin. Chem. Clin. Biochèn. 19, 115120.

40. Gardiner, P. E., Rösick, E., Rösick, U., Brätter, P. \& Kynast, G. (1982) Clin. Chim. Acta 120, 103-117.

41. Behne, D. \& Jürgensen, H. (1978) J. Radioanal. Chem. 42 , $447-453$.

42. Lilliefors, H. W. (1967) J. Amer̃. Statist. Assoç. 62, 399402.

43. Wainerdi, R. E. (1979) Pure \& Appl. Chem. 51, 1183=1193.

44. Pschyrembel, W. \& Dudenhausen, J. W. (1972), "Grundriß der Perinatalmedizin", S. 68-69. Walter de Gruyter, Berlin.

45. Iyengar, G. V., Kollmer, W. E. \& Bowen, H. J. M. (1978) "The Elemental Composition of Human Tissues and Body Fluids", Verlag Chemie, Weinheim.

46. Richterich, R. P. \& Colombo, J. P. (1978) „Klin̈ische Chemie", S. 440-441, 4. Aufl., Verlag. S. Karger, Basel.

47. Jürgensen, H. \& Behne, D. (1977) J J. Radioanal. Chem. 37, $375=382$.

48. Fujikara, R. \& Klionsky, B. (1975) Am. J. Obstet. Gynecol. $121,45-50$.

49. To be published.

Dr. Ullrich Rösick

Hahn-Meitner-İnst. f. Kernforschung

Bereich Kernchemie u. Reaktor

Glienicker Str. 100

D-1000 Berlin 39 


\section{Walter de Gruyter Berlin-New York}

\section{Wolfgang Voelter Günter Weitzel}

(Editors)
Structure and Activity of Natural Peptides Selected Topics

Proceedings of the Fall Meeting

Gesellschaft für Biologische Chemie

Tübingen, Germany, September 1979

$1981.17 \mathrm{~cm} \times 24 \mathrm{~cm}$. XII, 648 pages. Numerous illustrations.

Hardcover. DM 150,-; approx. US \$ 83.50

ISBN 3110082640

This volume is the result of selected contributions presented at the Fall Meeting of the Gesellschaft für Biologische Chemie in Tübingen in 1979.

CONTENTS (main chapters):

I. Surveys of Selected Topics. II. Isolation of New Peptides.

III. Methods of Purification, Isolation and Characterization of Peptides.

IV. Peptide Syntheses. V. Miscellaneous and Biological Activity of Peptides

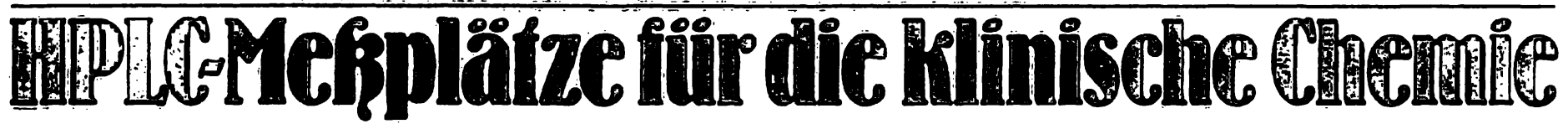

\section{zur Bestimmung von:}

Antiepileptika, Tranquillantia, Sedativa,.. Neuroleptika, Zystostatika usw.

\footnotetext{
Hauptanwendungsgebiete sind: Biochemische Forschung z.B. Bioverfügbarkeitstests.

Mónitoring z.B. für die Optimierung der Medikation, Compliance Tests.

Der Gynkotek-HPLC-MeBplatz für die klinische Chemie besteht aus folgenden Untereinheiten:Probenaufgabe und-aufbereltung

Automatischer Probengeber AS-1

oder ASI-3. Probenwaschpumpe Gynkotek - HPLC - Konstantflü pumpe M 600/200 oder M 300B. Probenanreicherung und -aufbereitung durch alternierende Vor säulenschaitung (System "Roth-
Beschkex) mit Vorsäulenrückspü-

lung (Backflush) mit dem Probenaufbereitungsmodul SE-2.

Alternativ: Probenaufbereitung über Bond-Eluter-Kartuschen mit integrierter, automatischerProbenaufgabe (Messeneuheit Pittssburgh Conference 1983).

HPLC-Grundeinheit

Eluentenfördersystem, Trennsäule, Detektionssystem: GynkotekHPLC-KonstantfluBpumpe M 600/ 200 oder M 300 B, Gynkotek-Niederdruckdoșiergradientenformer M 250 B, Gynkotek-Trennsäule, UVSpektralphotometer SP-4, Spek tralfluorometer RF-530.

Datenverarbeltung.

Chromatogrammauswertung, Da-
}

tenaufbereitungmittels BASIC-Proken Tabellen und graphischen Darstellungen, Datenübertragung auf andere Datensysteme: GynkotekHPLC-Datenstation C-R2AX.

Gynkotek erarbeitet maBgeschnoiderte Appllkationen fürdie klinische Chemie.

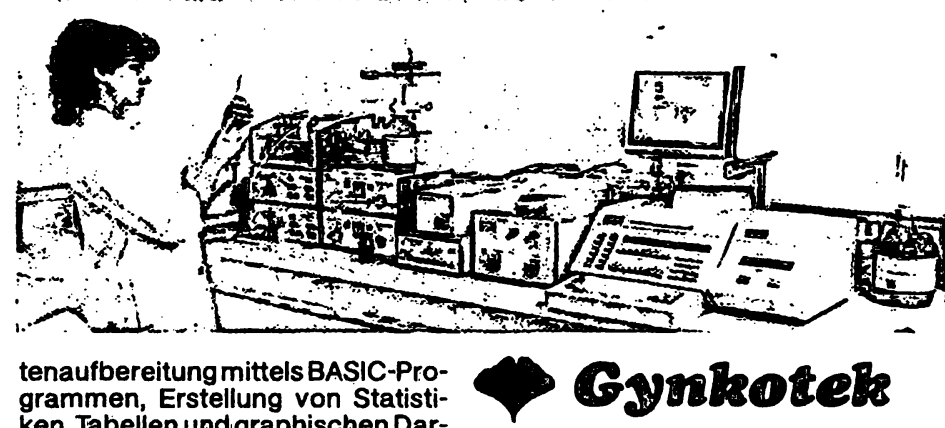

Gesellschaft für den Bau wissenschaftlich-technischer Geräte mbH

GunzenlehstraBe 24

D-8000 München 21

Tel. 089/582019

Telex: 528586 gynko d 


\section{Walter de Gruyter Berlin. New York}

\section{J. Büttner (Editor)}

\section{History of Clinical Chemistry}

1983. $18 \mathrm{~cm} \times 26 \mathrm{~cm} .91$ pages with illustrations. Hardcover. DM 98,-; approx. US \$44.75 ISBN 3110089122

Clinical Chemistry is a special discipline of medicine which, due to its close relationship both to medicine and to chemistry, is of particular interest to the historian of science.

This "History of Clinical Chemiștry" is based on a modérn outlöok on the history of science. Since the investigation of the history of clinical chemistry is still in progress, the book is divided into eight separate contributions, written primarily by historians of science, which together provide a good coverage of the history of Clinical Chemistry in the nineteenth century.

The book is written entirely in English and will therefore appeal to an international readership. Each contribution is provided with numerous notes and references.

\section{Contents}

Johannes Büttner · Introduction - Nikolaus Mani · The historical background of Clinical Chemistry - Joseph S. Fruton - Biochemistry and Clinical Chemistry. A retrospect - Erika Hickel The emergence of Clinical Chemistry in the 19th century. Presuppositions and consequences · Johannes Büttner · Johann Joseph von Scherer (1814-1869). A commentary on the early history of Clinical Chemistry - Hans $\mathrm{H}$. Simmer - Medicine and Chemistry around the middle of the 19th century in Erlangen: Eugen Franz Freiherr von Gorup-Besanez (1817-1878) · Johannes Büttner - Evolution of Clinical Enzymology - Johannes Büttner . Relationships between Clinical Medicine and Clinical Chemistry, illustrated by the example of the German-speaking countries in the late 19th century - Wendell T. Caraway - Major developmentș in clinical chemical instrumentation. 